\title{
Valuation of Ecological Resources
}

\author{
M. J. Scott \\ G. R. Bilyard \\ S. O. Link \\ P. F. Ricci \\ H. E. Seely \\ C. A. Ulibarri \\ H. E. Westerdahl
}

April 1995

Prepared for the U.S. Department of Energy under Contract DE-AC06-76RLO 1830

Pacific Northwest Laboratory Operated for the U.S. Department of Energy by Battelle Memorial Institute 


\section{DISCLAIMER}

This report was prepared as an account of work sponsored by an agency of the United States Government. Neither the United States Government nor any agency thereof, nor Battelle Memorial Institute, nor any of their employees, makes any warranty, expressed or implied, or assumes any legal liability or responsibility for the accuracy, completeness, or usefulness of any information, apparatus, product, or process disclosed, or represents that its use would not infringe privately owned rights. Reference herein to any specific commercial product, process, or service by trade name, trademark, manufacturer, or otherwise does not necessarily constitute or imply its endorsement, recommendation, or favoring by the United States Government or any agency thereof, or Battelle Memorial Institute. The views and opinions of authors expressed herein do not necessarily state or reflect those of the United States Government or any agency thereof.

\section{PACIFIC NORTHWEST LABORATORY operated by BATTELLEMEMORIAL INSTITUTE for the UNITED STATES DEPARTMENT OF ENERGY under Contract DE-AC06-76RLO 1830}

Printed in the United States of America

Available to DOE and DOE contractors from the

Office of Scientific and Technical Information, P.O. Box 62, Oak Ridge, TN 37831; prices available from (615) 576-8401. FTS 626-8401.

Available to the public from the National Technical Information Service, U.S. Department of Commerce, 5285 Port Royal Rd., Springfield, VA 22161. 


\section{DISCLAIMER}

Portions of this document may be illegible in electronic image products. Images are produced from the best available original document. 
PNL-10533

UC-630

\title{
Valuation of Ecological Resources
}

\author{
M. J. Scott \\ G. R. Bilyard \\ S. O. Link \\ P. F. Ricci \\ H. E. Seely \\ C. A. Ulibarri \\ H. E. Westerdahl
}

April 1995

Prepared for

the U.S. Department of Energy

under Contract DE-AC06-76RLO 1830

Pacific Northwest Laboratory

Richland, Washington 99352. 



\section{Executive Summary}

Ecological resources are resources that have functional value to ecosystems. Frequently, these functions are overlooked in terms of the value they provide to humans. Environmental economics is in search of an appropriate analysis framework for such resources. In such a framework, it is essential to distinguish between two related subsets of information: 1) ecological processes that have intrinsic value to natural ecosystems, e.g., provision of vegetative cover, and 2) ecological functions that are valued by humans, e.g., provision of cleaner air. The present study addresses these concerns by identifying a habitat that is being displaced by development, and by measuring the human and ecological values associated with the ecological resources in that habitat. It is also essential to determine which functions are mutually exclusive (e.g., farming vs. soil stabilization) and which are, in effect, complementary or products of joint production (e.g., soil stabilization and recreation).

We apply several resource valuation tools, including contingent valuation methodology (CVM), travel cost methodology (TCM), and hedonic damage-pricing (HDP). One way to derive upper-limit values for more difficult-to-value functions is through the use of "human analogs," because humanengineered systems are relatively inefficient at supplying the desired services when compared with natural systems. Where data on the relative efficiencies of natural systems and human analogs exist, it is possible to adjust the costs of providing the human analog by the relative efficiency of the natural system to obtain a more realistic value of the function under consideration.

We demonstrate this approach in an environmental economic case study of the environmental services rendered by shrub-steppe habitats of Benton County, Washington State. Shrub-steppe is the dominant land cover across vast areas of the Intermountain West and Northern Mexico. It is often considered unattractive, poor-quality grazing land, but can also be developed for farming or urban uses where sufficient water exists. Most developed uses of the land base are mutually exclusive, resulting in market values that recognize this exclusivity. Any complementary natural functions ordinarily go unpriced. Annualized values in Benton County for various human uses of the land average as follows:

- Grazing: \$3.35/acre/year

- Dryland Farming: \$12.40/acre/year

- Irrigated Farming: \$74.20/acre/year

- Urban: $\$ 460.40 /$ acre/year.

In its natural state, shrub-steppe habitat jointly provides numerous functions, including recreation, soil stabilization, and biological diversity, regulation of water flow, education, carbon fixing, and climate 
moderation. Because they are not mutually exclusive, the values of these functions can be added together. However, data are very limited on all but the soil stabilization, recreational hunting, and biodiversity functions.

Soil stabilization improves aesthetics, reduces traffic hazards due to blowing dust, reduces household cleaning costs, and may slightly improve respiratory health of the human population. Contingent valuation study results, when applied to Benton County, result in relatively low values for shrubsteppe habitat--between \$4 and \$14/acre/year. Traffic accidents and road closures cost between \$15 and $\$ 52 /$ acre/year, while extra cleaning costs may be between $\$ 48$ and $\$ 169 /$ acre/year. Costs of retaining soil range between $\$ 6$ and $\$ 21 /$ acre/year if the land is farmed, and amount to about $\$ 47$ I acre/year if the land is set aside in the U.S. Department of Agriculture's Conservation Reserve Program and seeded to a natural grass cover. The value to changes in respiratory health appears to be less than $\$ 1 /$ acre/year.

Hunting values average about \$6/acre/year (casual upland bird hunting, as measured by travel cost techniques) up to about $\$ 75 /$ acre (if the land is set aside exclusively for hunting).

Finally, the value of species diversity, as measured by the costs and the relative effectiveness of human habitat restoration analogs is about $\$ 52$ to $\$ 75 /$ acre/year.

The highest values of natural shrub-steppe habitat appear to be based on soil stabilization. Attention to mitigation and maintaining ground cover to prevent blowing dust in inhabited regions could reduce offsite damage from soil erosion. Similarly, grazed and farmed areas could be managed to maintain some important recreation values. However, the biodiversity value cannot be finessed through mitigation.

This paper does not discuss whether an appropriate balance has been struck between developed and undeveloped land in the shrub-steppe parts of the West. However, it does suggest that whenever development occurs, the processes and functions of the natural habitat should be investigated, and attention should be given to low-cost ways to preserve these functions--even those functions that have no easily recognized market value. 


\section{Acknowledgments}

The authors wish to acknowledge the assistance and suggestions of J. A. Wise, L. E. Rogers, D. A. Neitzel, C. A. Brandt, S. L. Friant, K. M. Probasco, C. A. McAllister, C. W. Abrams, R. N. Kickert, and members of the Pacific Northwest Laboratory (PNL) Technology Planning and Analysis Center's Technical Advisory Group. This paper was prepared with internal research and development funds of PNL, which is operated for the U.S. Department of Energy by Battelle Memorial Institute. The views expressed are those of the authors and do not necessarily represent those of the U.S. Department of Energy or of Battelle Memorial Institute. 



\section{Contents}

Executive Summary $\ldots \ldots \ldots \ldots \ldots \ldots \ldots \ldots \ldots \ldots \ldots \ldots$ iii

Acknowledgments $\ldots \ldots \ldots \ldots \ldots \ldots \ldots \ldots \ldots \ldots \ldots \ldots \ldots \ldots$

Valuation of Ecological Resources $\ldots \ldots \ldots \ldots \ldots \ldots \ldots \ldots$

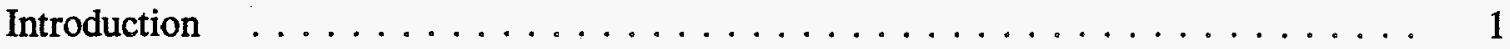

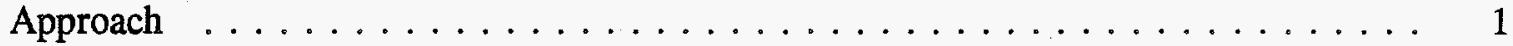

Elements of Ecological Resource Valuation $\ldots \ldots \ldots \ldots \ldots \ldots$

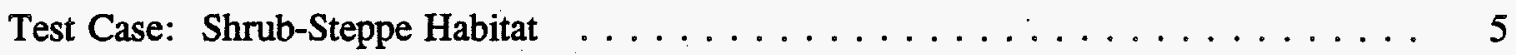

Environmental Processes, Functions, and Services $\ldots \ldots \ldots \ldots \ldots$

Characteristics of the Shrub-Steppe Habitat $\ldots \ldots \ldots \ldots \ldots$

Functions and Services of Shrub-Steppe Habitat $\ldots \ldots \ldots \ldots \ldots$

Effects of Disturbance on Shrub-Steppe Processes, Functions, and Services $\ldots \ldots$

Valuation of Shrub-Steppe Ecosystem Functions $\ldots \ldots \ldots \ldots \ldots \ldots \ldots$

Opportunity Costs of Preservation $\ldots \ldots \ldots \ldots \ldots \ldots \ldots \ldots$

Estimating Resource Values $\ldots \ldots \ldots \ldots \ldots \ldots$

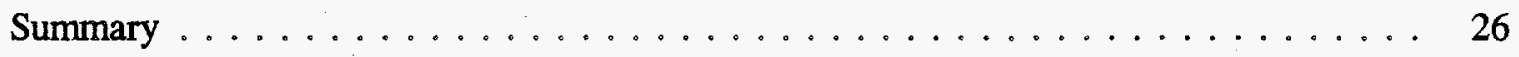

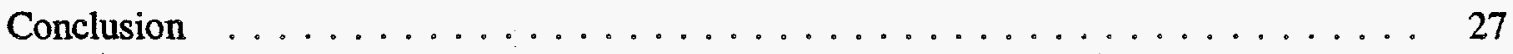

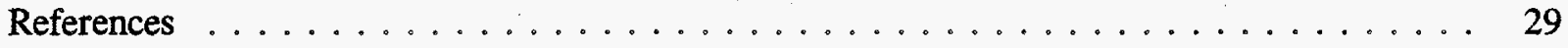




\section{Figures}

1 Marginal Valuation of Natural Landscapes Versus Development . . . . . . . . . . . 4

2 Location of the Fitzner/Eberhardt Arid Lands Ecology Reserve on the Hanford Reservation in South-Central Washington State $\ldots \ldots \ldots \ldots$

3 Estimated Household Cleaning Costs Associated with Soil Erosion in Benton and Franklin Counties, Washington $\ldots \ldots \ldots \ldots \ldots \ldots$

4 Aggregate Willingness-to Pay for Hunting Upland Game Birds in Benton and

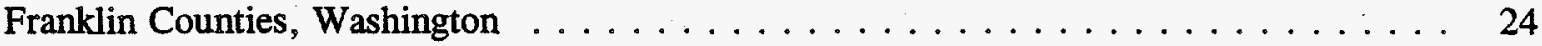

\section{Tables}

1 Processes, Functions, and Services of Shrub-Steppe Habitat $\ldots \ldots \ldots \ldots$

2 Traffic Safety in Benton-Franklin Counties $\ldots \ldots \ldots \ldots$. . . . . . . . . . . 9

3 Health Effects in Benton-Franklin Counties $\ldots \ldots \ldots \ldots \ldots \ldots$

4 Effects of Disturbances on Quality Scores for Environmental Dimensions of Shrub-Steppe Habitat Measured at Fitzner-Eberhardt Arid Lands Ecology Reserve . . . . 11

5 Summary Statistics of Land Value Per Acre, 1993-1994, Benton County, Washington $\ldots \ldots \ldots \ldots \ldots \ldots \ldots$

6 Estimated Costs of Conservation Reserve Program Compared to Average Prices of Various Types of Land, in Benton and Franklin Counties, Washington . . . . . . . . 22

7 Summary of Values Estimated for Shrub-Steppe Habitat . . . . . . . . . . . 27 


\section{Valuation of Ecological Resources}

\section{Introduction}

Ecological resources are defined in this paper as those resources that have functional value to ecosystems but are frequently overlooked in terms of providing values to humans. Aside from selected wetland studies, e.g., Barbier (1994); Constanza, Farber, and Maxwell (1989); Batie and Zeno (1985); and Gupta and Foster (1975), little attention has been given to the valuation of ecological resources in comparison to their more "glamorous cousins," e.g., endangered species or unique wilderness sites. Moreover, the attention that has been given to ecological resource values has focused mostly on values that are generated through human consumptive and non-consumptive uses as opposed to environmental functions per se. We believe this relatively narrow focus contributes in only a limited way to an understanding of the social costs and benefits of policy choices bearing on the functional value of ecological resources.

The central question explored in this paper is a simple one: can defensible estimates of ecological resource values be derived? As in any emerging field, the present-day understanding of ecological resource values is limited by difficulties in obtaining confident empirical measurements. The estimation of accurate value measures is complicated by the fact that ecological services are often subtle, and may require considerable technical understanding to be fully appreciated. Consequently, their values may not readily be perceived by humans. A desirable approach to the valuation of ecological resources would be sensitive to the extent of capturing their importance to the ecosystem, while recognizing their potential direct and indirect value in consumptive and non-consumptive uses. The present study takes an alternative approach in addressing these empirical concerns using a specific set of ecological resources associated with arid land environments and a mix of resource valuation techniques.

The key objectives of the present study are to provide an ecological valuation framework that: 1) aggregates the values of goods and services rendered by selected ecological functions, and 2) determines defensible upper and lower limits on the value of these resources. We believe that interpolating between these limits will provide more comprehensive and realistic estimates of the value of ecologically derived goods and services, thereby providing policy makers with a better understanding of the social costs and benefits of ecological preservation.

\section{Approach}

We hypothesize that the upper-limit values of ecological resources are best approximated by the costs of providing them through human-engineered systems, or "human analogs." This is because humanengineered systems are relatively inefficient at performing ecological functions when compared to natural ecosystems. An example is soil stabilization in arid environments through the planting and irrigation of non-indigenous plant species, compared to simply preserving these environs in their natural state. 
The present study provides conceptual and empirical measures of upper- and lower-limit ecological resource values by applying alternative valuation techniques. Consumptive and non-consumptive use values, as perceived either directly or indirectly by people, are estimated using the method of benefit transfers (Brookshire and Neil, 1992; Boyle and Bergstrom, 1992). Using this method, researchers employ supporting information in the process of adapting existing environmental valuation estimates to new study sites. Our study adapts contingent valuation (CVM) estimates of the aesthetic value of air quality (Rowe et al., 1980), travel-cost (TCM) estimates of the recreational value of upland game hunting sites (Adams, et al., 1989), and hedonic price (HDP) estimates of the value of reduced offsite wind erosion (Huszar, 1989).

The more difficult-to-measure values of natural ecosystems are estimated using a replacement cost methodology. Replacement costs consider the costs of replacing the functions performed by natural ecosystems through human-engineered analogs. Where data exist on the relative efficiencies of natural systems over manmade systems, we discount the costs of providing the human-engineered analog by the relative efficiency of the natural ecosystem. We believe this obtains a more realistic measure of ecological resource values. Conceptually, this approach is consistent with the principal of comparative economic advantage, where the existence of a less expensive manufacturing process undercuts the production costs of relatively more expensive production processes.

The most difficult conceptual problem confronted in the present study is the process of defining linkages between ecological functions and the benefits these confer on people. This problem is most visible in the elicitation of CVM estimates of ecological resources. Unlike other resource values, whose functions or processes are better understood, ecological resources require considerable understanding of what is at stake when the integrity of an ecological resource is compromised. Thus, we suspect CVM estimates tend to underestimate ecological resource values. Accordingly, the maintained hypotheses of the present study are twofold: 1) that upper-limit values of ecological resources are best approximated by the costs of human analogs, and 2) that lower-limit values of ecological resources are best approximated by CVM estimates.

Our study focuses on estimates of the values of ecological functions and services rendered by shrubsteppe habitat of the intermountain West. The value of this habitat has often been overlooked in urban and agricultural planning decisions in the western United States. In its natural state, this habitat maintains a vegetative cover that minimizes soil erosion while controlling water filtration. It also serves as a vegetative cover and food supply for numerous species of mammals and birds while providing climate moderation (Rogers et al., 1988).

\section{Elements of Ecological Resource Valuation}

Our valuation framework identifies a set of environmental functions and services to be valued in subsequent sections of the paper. A case study involving environmental services rendered by shrub-steppe habitats in the western United States provides a useful demonstration. Shrub-steppe is the dominant land cover across vast areas of the intermountain West and Northern Mexico. It is often considered unattractive, poor-quality grazing land that is usable for agricultural and/or urban development when 
supplemental water is available. Meanwhile, shrub-steppe land left in its natural state often goes unnoticed by the general public and land use planners in terms of providing valuable ecological services or recreational uses.

Nationally, we denote the economic benefits of ecological services and uses of shrub-steppe by the value function $\mathrm{V}(\mathrm{A})$, where $\mathrm{A}$ represents shrub-steppe acreage. The costs of deriving these benefits reflect the economic tradeoffs (i.e. opportunity costs) in forgoing urban and agricultural development. These opportunity costs are denoted by $\mathrm{C}(\mathrm{A} \mid \mathrm{U})$, and are conditional upon alternative land use (U). To some degree these opportunity costs are accounted for by "fair market values" of shrub steppe in the relevant real estimate market. Real estate appraisers frequently assign fair market values to shrubsteppe sites based on their capacity to support livestock, and other amenities that facilitate converting the land to urban or agricultural use. Deducting these opportunity costs from the value function yields the net preservation value through the following maximizing condition:

$$
V^{\prime}(A)-C^{\prime}(A \mid U)=0 \text {,at } A=A^{*}
$$

where $\mathrm{A}^{*}=$ the economically preferred amount of shrub-steppe acreage to preserve.

Under this maximizing condition, the additional value from preserving an acre is just sufficient to compensate society for the additional opportunity costs. Much of the preservation value these sites have depends on their ecological functions and processes.

We maintain that much of the preservation value of shrub-steppe sites depends on their ecological functions and processes. Because shrub-steppe habitats perform many ecological functions simultaneously, they embody elements of what economists refer to as "joint production." Moreover, when the benefits from their ecological services are available to many people at the same time, without having to pay anything for them, shrub-steppe sites have the characteristics of "public goods." As a rule, private markets are very bad at producing public goods. Speaking for economists, Kneese (1984) notes that "there usually is no private incentive to produce them at all, because while many people could benefit from them, no single individual usually has a sufficient incentive to pay for them." We illustrate the public-goods nature of shrub-steppe ecosystems in Figure 1 by considering the marginal value curves of two functions, soil stabilization $\left(\mathrm{MV}_{\mathrm{s}}\right)$ and biological diversity $\left(\mathrm{MV}_{\mathrm{b}}\right)$.

In the natural state, these services are provided simultaneously without one impinging on the other. Assuming these services are valued by society, their joint marginal value would be represented by the aggregate marginal value curve for acres of preserved land, $\mathbf{M V}_{\mathrm{T}}$, (shown by the kinked curve sloping downward to the right). Meanwhile, the opportunity cost curves of forgoing land development having low and high values (e.g., farmland when crop prices are low and.high) are shown by upward sloping marginal cost curves. If both ecological values of land exist and are correctly accounted for, the socially efficient amount of preservation would occur at point $A$, with $A_{T}$ acres preserved at the total marginal value of $\mathrm{MV}_{\mathrm{Tl}}$. This aggregate marginal value is just sufficient to compensate the land owner in forgoing the development of a unit of land. 


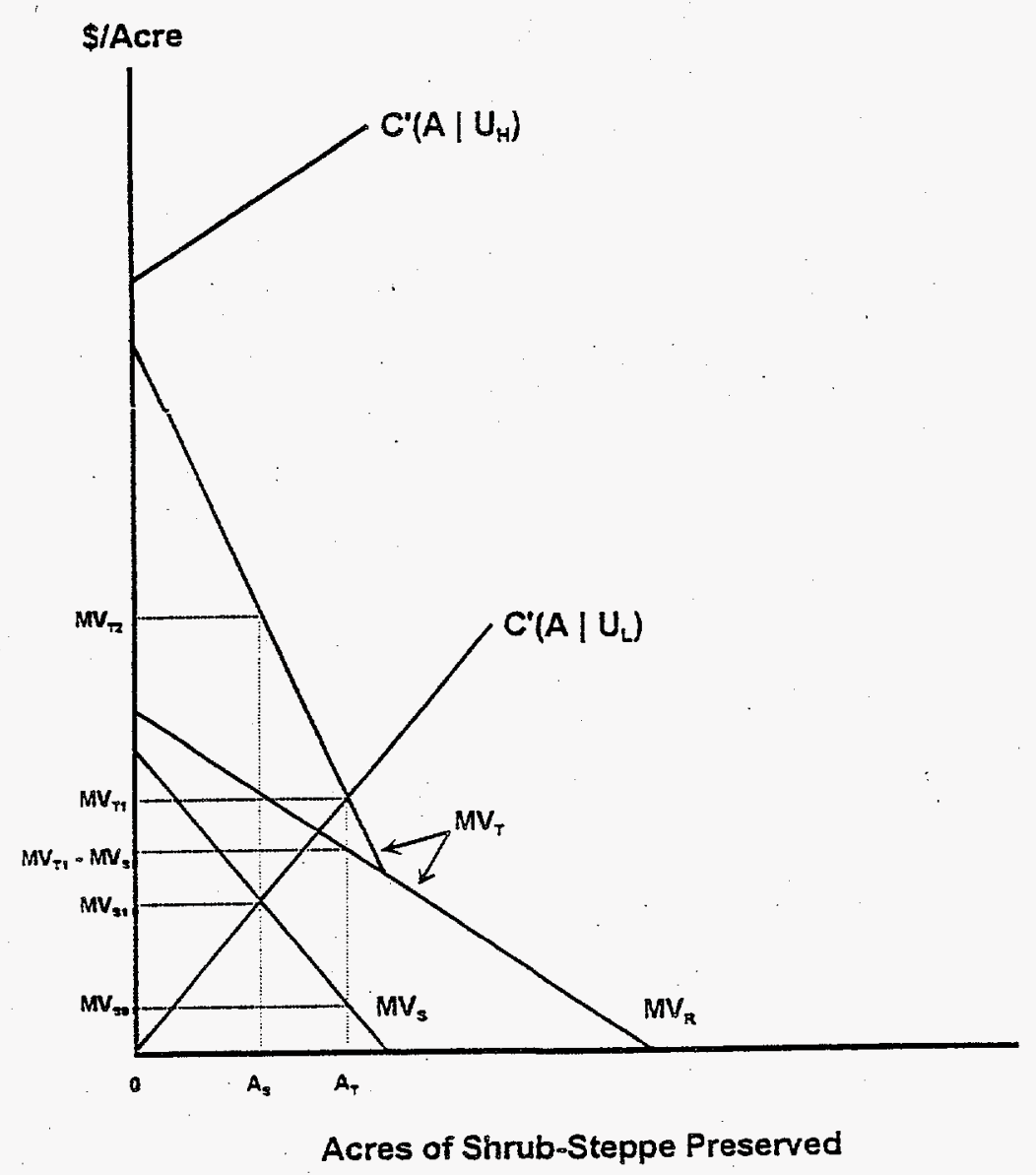

Figure 1. Marginal Valuation of Natural Landscapes Versus Development

The above result describes the allocation of shrub-steppe land between preservation and developmental uses, taking into account the existence of both ecological values. However, because one (if not both) of the ecological values embodied in $\mathbf{M V}_{\mathrm{T}}$ possess the characteristics of public goods, the benefits of preservation do not accrue exclusively to buyers of the land. Consequently, if no consideration is given to the marginal value of one of these ecological functions, say biodiversity, the amount of acreage preserved would decline from $A_{T}$ to just $A_{s}$. In this case, $M_{S}$ would reflect the marginal value of preserved land corresponding to its soil stabilization function, while the implicit value of the land would actually rise to $\mathrm{MV}_{\mathrm{T}}^{2}$, reflecting a relative increase in the scarcity of preserved land. Finally, we consider the case where the opportunity cost of forgoing land development increases dramatically, as represented along the upper marginal cost curve. Here, no land would be set aside for preservation due to the relatively lower total marginal value of preservation when compared to development. Of course, a similar result would obtain if both ecological values are overlooked. 
Clearly, this conceptual abstraction of ecological resource valuation is oversimplified. Shrub-steppe land actually provides many other ecological functions besides soil stabilization and biological diversity. The vegetation in natural shrub-steppe habitats minimizes water erosion (Link et al., 1995). In addition, shrub-steppe habitat provides educational, recreational and carbon fixation function (Rogers et al., 1988). However, limited data are available to quantify these latter functions or several of the recreational activities ordinarily conducted on shrub-steppe habitats. For example, data are available for advanced scientific studies of shrub-steppe habitats, but not for primary and secondary educational activities. Therefore, the remainder of the paper concentrates on the measurement of ecological resource values associated with soil stabilization, biodiversity, and game habitat.

\section{Test Case: Shrub-Steppe Habitat}

Relationships between environmental processes, functions, and services, characteristics of shrub-steppe habitats, and the effects of disturbance on shrub-steppe processes, functions, and services are summarized below. It is necessary to understand the processes, functions, and services to understand their value.

\section{Environmental Processes, Functions, and Services}

For purposes of valuing ecological resources, it is useful to distinguish between environmental processes (historically, the domain of ecologists), environmental functions (those aspects of the environment valued by humans), and services (those attributes of environmental functions that directly or indirectly benefit humans). The shrub-steppe habitat involves a large array of complex chemical and biological processes and interdependent organisms. Many of these processes matter only to the organisms themselves. However, healthy operation of these processes gives rise to a number of functions that are valued implicitly or explicitly by human beings. When the underlying ecological components and processes are at risk, so are many of the functions and services derived from them (Table 1).

\section{Characteristics of the Shrub-Steppe Habitat}

We gain the necessary ecological perspective on how shrub-steppe sites perform these functions by referring to various studies conducted at the Fitzner/Eberhardt Arid Lands Ecology (FEALE) Reserve on the Hanford Site in south-central Washington State (Figure 2). While FEALE is not entirely representative of all shrub-steppe habitat, experiments conducted at this site over the last 40 years shed considerable light on the shrub-steppe ecological processes. Information from FEALE is supplemented with information from nearby shrub-steppe habitats in the following discussion.

The $312 \mathrm{~km}^{2}$ FEALE Reserve is situated on the northeast-facing flank of the Rattlesnake Hills, a long anticlinal ridge, varying in elevation from 150 to $1100 \mathrm{~m}$. The area is semi-arid with hot dry summers and cool wet winters. Average yearly precipitation ranges from $260 \mathrm{~mm}$ at the higher elevations to $160 \mathrm{~mm}$ in the lower areas, falling mostly in the fall and winter (Thorp and Hinds, 1977). 
Table 1. Processes, Functions, and Services of Shrub-Steppe Habitat

\begin{tabular}{|c|c|c|}
\hline Processes & Function & Service \\
\hline Plant growth & Soil stabilization & $\begin{array}{l}\text { Reduced } \mathrm{PM}_{10} \text { count: } \\
\text { improved aesthetics, } \\
\text { reduced respiratory prob- } \\
\text { lems; reduced productivity } \\
\text { loss through soil erosion; } \\
\text { fewer traffic accidents and } \\
\text { road closures; less house- } \\
\text { hold cleaning }\end{array}$ \\
\hline Ecosystem dynamics & Recreation & $\begin{array}{l}\text { Hunting, horseback riding, } \\
\text { nature hikes, birdwatching }\end{array}$ \\
\hline $\begin{array}{l}\text { Nutrient cycling, water retention, } \\
\text { photosynthetic capture }\end{array}$ & Biological diversity & Species maintenance \\
\hline Water Capture & Water retention & $\begin{array}{l}\text { Groundwater recharge; } \\
\text { reduced flooding }\end{array}$ \\
\hline $\begin{array}{l}\text { Ecosystem existence and } \\
\text { maintenance }\end{array}$ & Education and research & $\begin{array}{l}\text { System components for } \\
\text { study }\end{array}$ \\
\hline $\begin{array}{l}\text { Evapotranspiration, gas } \\
\text { exchange, temperature } \\
\text { modification }\end{array}$ & $\begin{array}{l}\text { Climate moderation, } \\
\text { micro-climate } \\
\text { availability }\end{array}$ & $\begin{array}{l}\text { Niches for biota. } \\
\text { Processes contribute to } \\
\text { maintenance of local and } \\
\text { regional climate. }\end{array}$ \\
\hline
\end{tabular}

The vegetation of the area is dominated by Pseudoregneria spicata (bluebunch wheatgrass), Artemisia tridentata (big sagebrush), Poa sandbergii (Sandberg's bluegrass), and Bromus tectorum (cheatgrass). Because the area has been subjected to frequent fires, approximately $80 \%$ of FEALE is dominated by $P$. spicata (Rogers and Rickard, 1988). Soils are mainly Warden and Ritzville silt loams grading into sandy loams and sands at lower elevations. 


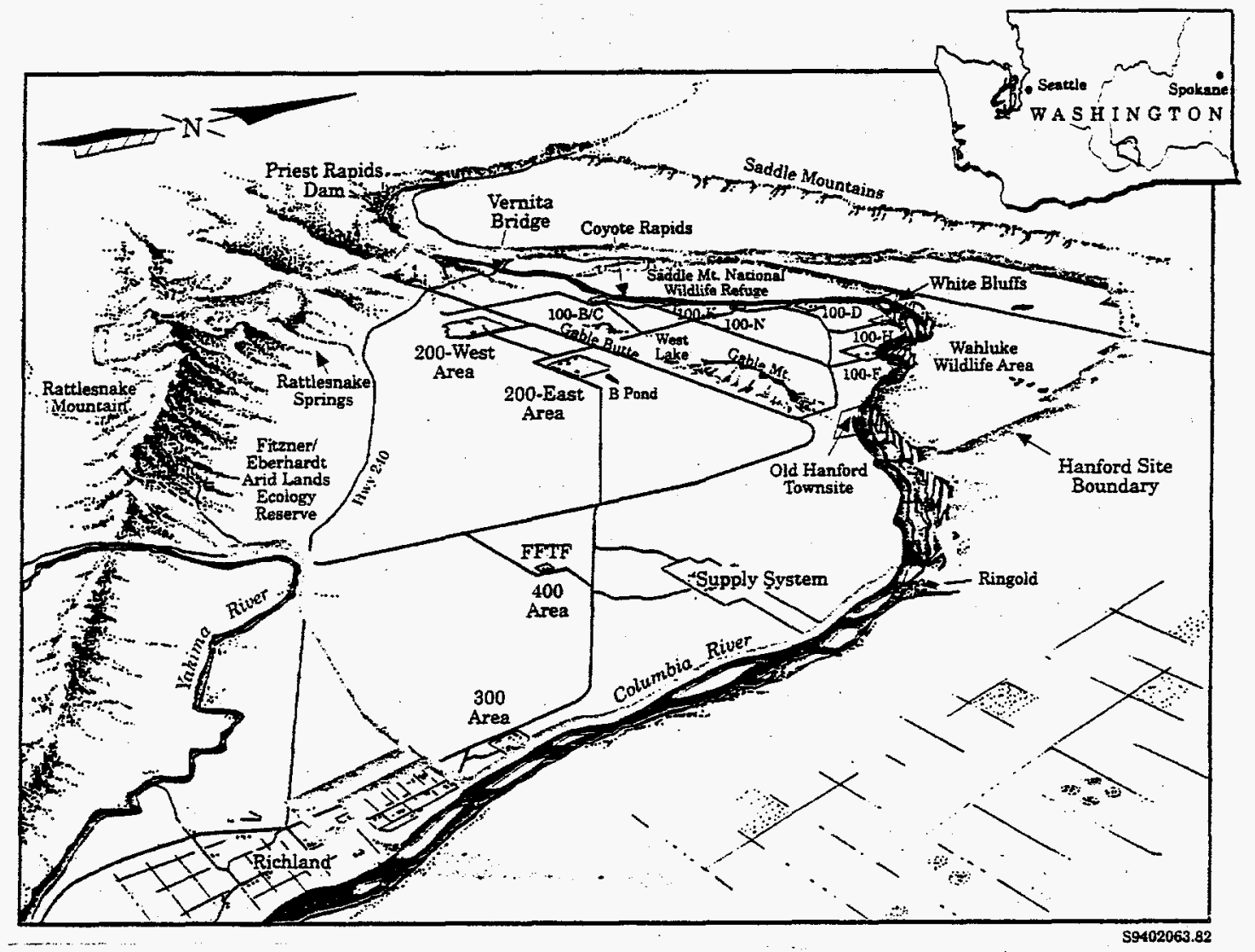

Figure 2. Location of the Fitzner/Eberhardt Arid Lands Ecology (FEALE) Reserve on the Hanford Reservation in South-Central Washington State

\section{Functions and Services of Shrub-Steppe Habitat}

Below we discuss the soil stabilization, recreational hunting, and biological functions of shrub steppe habitat. Water retention, public education, and climate functions are not considered because data were insufficient for their valuation. The biological function is discussed in the context of the effects of disturbance.

\section{Soil Stabilization}

Land cover is critical in reducing wind erosion and the impact of fugitive dust on human populations. The Benton-Franklin County study area has a long history of seasonal dust storms and accompanying air quality problems. These events often occur during Spring and Fall, and are the byproduct of catastrophic wind erosion of fallow farmland. On some fields the loss has been estimated to be as much as 700 tons of soil per acre from September through November, or about two inches of topsoil (Wohld, 1991). Besides the loss of topsoil and nutrients, other seedlings on adjacent arid lands are seriously damaged. Moreover, the fugitive dust emissions from dryland farms are widely believed to be the single major source of air quality problems experienced in the Benton-Franklin County area. 
Wind erosion is dependent on a variety of factors, most notably, soil moisture, soil type, ground cover, and wind velocity. According to Holmes (1994), pristine shrub-steppe lands have an annual erosion rate between one-half and one ton per acre. Meanwhile, cropland in the two-county area experiences an annual wind erosion rate of 10-15 tons/acre-approximately the width of a dime (Holmes, 1994).

Fugitive dust is a non-point source of pollution based on the Environmental Protection Agency's (EPA's) National Ambient Air Quality Standards (NAAQS). Under these standards, particulate matter (PM) measurements in a given area must not exceed $150 \mu \mathrm{g} / \mathrm{m}^{3}$ over a 24-hour period, and/or an average level of $50 \mu \mathrm{g} / \mathrm{m}^{3}$ over a 1-year period. Relative to these safety standards, the Benton-Franklin County region experienced 11 days of non-compliance over a 2-year period, from October 16, 1991 through May 13, 1993. According to the Benton County Clean Air Authority, the three highest PM $_{10}$ levels recorded in the two-county area are among the worst on record in the U.S. (Wohld, 1991). The principal cause has been attributed to airborne dust. The three worst events correlated with high winds from the southwest under dry conditions. Neighboring farmlands have been the focus of attention in the violation of $\mathrm{PM}_{10}$ concentration standards; in particular, the practice of dryland farming on the Horse Heaven Hills in southwest Benton County (Whold, 1991). The most notable exceedence events are identified in Table 2, along with data on automobile collisions caused by impaired visibility.

Traffic Safety. Reduced visibility on rural roads and interstate highways on $\mathrm{PM}_{10}$ exceedence dates suggests the possibility of exploring a hedonic damage value for automobile collisions and injuries sustained during severe dust storms. The traffic accident information reported in Table 2 was obtained from the Washington State Traffic Safety Commission and gives the numbers of reported collisions and injuries on high $\mathrm{PM}_{10}$ days relative to $\mathrm{PM}_{10}$ days for 1991-1993.

Respiratory Effects. Acute respiratory effects also are associated with severe dust storms. An examination of these respiratory effects in Benton-Franklin Counties was undertaken by Hefflin et al. (1994). These authors considered the impacts of $\mathrm{PM}_{10}$ levels above $1000 \mu \mathrm{g} / \mathrm{m}^{3}$ on the number of emergency room (ER) visitations for respiratory disorders. Their study calculated the annual, monthly, and daily number of ER visits for respiratory disorders, and made correlations between ER visits, $\mathrm{PM}_{10}$ levels, and meteorological conditions (see Table 3).

\section{Recreation}

Shrub-steppe land in the study region provides an open space for a variety of recreational uses, including upland game hunting. The recreational value of shrub-steppe land as hunting sites, depends on the environmental attributes of any given site.

Based on survey data, state game officials estimated 8,062 pheasant/quail hunters used the BentonFranklin County area in 1991 (Wildlife Management Division, 1993). A variety of game birds are distributed throughout this region, requiring a diverse habitat that includes both open space for feeding and brushy cover for protection. Upland bird hunting is particularly notable near cultivated lands and surface water bodies. 
Table 2. Traffic Safety in Benton-Franklin Counties

\begin{tabular}{lccc}
\hline $\begin{array}{c}\text { Exceedence } \\
\text { Dates }\end{array}$ & $\begin{array}{c}\mathrm{PM}_{10} \\
\left(\mu \mathrm{g} / \mathrm{m}^{3}\right)\end{array}$ & Collisions & Injuries \\
\hline $10 / 16 / 91$ & 1689 & 8 & 4 \\
$11 / 03 / 93$ & 1166 & 7 & 3 \\
$10 / 21 / 91$ & 1035 & 3 & 1 \\
$9 / 08 / 92$ & 596 & 5 & 2 \\
$4 / 05 / 91$ & 350 & 4 & 4 \\
$4 / 02 / 91$ & 281 & 4 & 2 \\
$12 / 12 / 91$ & 212 & 3 & 2 \\
$9 / 26 / 92$ & 183 & 4 & 5 \\
$8 / 18 / 91$ & 174 & 2 & 4 \\
$1 / 29 / 91$ & 165 & 4 & 0 \\
$5 / 13 / 93$ & 155 & 3 & 4 \\
\hline
\end{tabular}

Source: Personal communication with Charlie Fable, Washington State Traffic Commission, August 25, 1994.

Agriculture and intensive grazing tend to reduce native food sources and cover for upland game birds (Washington State Department of Fish and Wildlife, 1994). Despite this fact, there remains a large population of valley or California quail (Callipepla californica). These birds are ranked third in upland bird harvests in Washington State, with an annual average harvest of 110,420 . In the Benton-Franklin County area, an average of 12,871 quail are harvested each year (Washington State Department of Fish and Wildlife, 1994). Ring-necked pheasant (Phasianus colchicus) also inhabit agricultural and riparian areas in southeastern Washington. Pheasant feed primarily on cultivated grains but also feed on weed and grass seeds, wild fruits, and insects (Washington State Department of Fish and Wildlife, 1994). While agriculture provides some of the food, pheasant also require woody and thorny plants for cover which can be found on most shrub-steppe lands. Ring-necked pheasant are Washington's most popular game bird with an average annual harvest of 161,676. Average harvest in the Benton-Franklin County area is nearly 20,000 (Washington State Department of Fish and Wildlife, 1994).

Other popular game birds that reside in Benton and Franklin Counties include the chukar (Alectoris chukar) and gray partridge (Perdix perdix). Chukar reside almost exclusively within shrub-steppe habitat and feed primarily on cheatgrass, seeds, shrub fruits, and insects. Partridge require a combination 
Table 3. Health Effects in Benton-Franklin Counties

\begin{tabular}{lccc}
\hline \hline $\begin{array}{l}\text { Respiratory } \\
\text { Disorder }\end{array}$ & $\begin{array}{c}\text { E.R. Visits } \\
\text { (Oct. 1-30, 1991) }\end{array}$ & $\begin{array}{c}\text { Expected } \\
\text { E.R. } \\
\text { Visits }\end{array}$ & $\begin{array}{c}\text { Number of } \\
\text { Unexpected } \\
\text { E. R. Visits }\end{array}$ \\
\hline Otitis media & 246 & 210 & 36 \\
Bronchitis & 235 & 210 & 25 \\
URI & 222 & 184 & 38 \\
Pharyngitis & 176 & 163 & 13 \\
Sinusitis & 44 & 56 & $(12)$ \\
Asthma & 28 & 36 & $(8)$ \\
Pneumonia & 33 & 32 & 1 \\
Influenza & 18 & 16 & 2 \\
COPD & 8 & 11 & $(3)$ \\
Croup & 17 & 25 & $(8)$ \\
Bronchiolitis & 2 & 2 & 0 \\
\hline Source: Hefflin et al., 1991. & & \\
\hline \hline
\end{tabular}

of open shrub-steppe land and cropland as habitat and feed mainly on cultivated grains, native plant seeds, and insects. The annual sport harvest in Washington averages 40,026 for chukar and 17,283 for partridge. In the Benton-Franklin County area, harvests average 1,937 and 659 for chukar and partridge, respectively (Washington State Department of Fish and Wildlife, 1994).

\section{Effects of Disturbance on Shrub-Steppe Processes, Functions, and Services}

As has happened throughout much of the Intermountain West, the shrub-steppe habitat at FEALE has been disturbed by farming and grazing. Because the area has restricted access due to its national defense uses, the consequences of disturbances have been documented over the last 40 years and can be used to calibrate our valuation process (Rogers et al., 1988).

Disturbances have adversely affected water, air, soil, and biotic quality of the FEALE Reserve.

Table 4 ranks these resources on the FEALE Reserve using a rank of zero (for low quality) to 1 (for high quality). For example, when water is clean but not available for recharge to groundwater, it may be of high value to the ecosystem but of little direct value to humans. On the other hand, water contaminated with agricultural chemicals and fertilizers, though available, may also be of low value. Soil quality is closely tied to biotic quality. A low-quality soil is one that is greatly disturbed and has lost 
Table 4. Effects of Disturbances on Quality Scores for Environmental Dimensions of Shrub-Steppe Habitat Measured at Fitzner-Eberhardt Arid Lands Ecology (FEALE) Reserve

\begin{tabular}{lccc}
\hline & & \multicolumn{2}{c}{ Plant Biotic Quality } \\
\cline { 3 - 4 } \multicolumn{1}{c}{ Disturbance } & $\begin{array}{c}\text { Soil } \\
\text { Quality }\end{array}$ & Biomass & $\begin{array}{c}\text { Species } \\
\text { Number }\end{array}$ \\
\hline Undisturbed shrub-steppe & 1.0 & 1.0 & 1.0 \\
Short-term grazing & $<1.0$ & 1.0 & $<1.0$ \\
$\begin{array}{l}\text { Old-field conditions } \\
\text { (long-term recovery) }\end{array}$ & 1.0 & 0.7 & 0.6 \\
\hline \hline
\end{tabular}

much of its organic and nutrient content near the surface. Biotic quality is a measure of the biotic complexity and mass of an ecosystem. Low complexity is associated with disturbances where biological diversity has been reduced. An ecosystem that has high biological complexity is likely to have high air, water, and soil quality. Such systems have also been defined as having high integrity

(King, 1993).

Identifying the source(s) of ecological risks and damages is a critical step in the process of valuing ecological resources. Shrub-steppe sites and their ecological elements are subject to risk from a variety of sources, including natural disturbances (e.g., fires) and human-induced disturbances (e.g., extension of agriculture and urban sprawl). Although considerable scientific uncertainty exists concerning the extent of the ecological damages that result from clearing shrub-steppe sites for alternative uses, the argument that ecological injuries arise in the process of converting shrub-steppe lands to alternative uses provides the motivation for undertaking an economic valuation of the ecological functions performed by natural shrub-steppe lands. These injuries may be temporary or permanent.

\section{Plowing}

The short- and long-term effects of plowing have been studied extensively on FEALE. Some of these studies compared disturbed and undisturbed shrub-steppe ecosystems. For example, wheat farming had been done at Lower and Upper Snively fields prior to 1943. Cessation of farming activities in these areas permits an evaluation of long-term ecological response. These fields are now composed of annual weeds, with Bromus tectorum the dominant species (Rickard et al., 1988).

In addition, the short-term response of the ecosystem to plowing has been investigated (Rickard and Vaughan, 1988). The effect of recent plowing on two old-field weed communities (Lower and Upper 
Snively fields) was documented from 1974 to 1976 . Plowing was done on two $10 \times 20-\mathrm{m}$ strips in both communities. Soil and biotic characteristics were measured, although air and water characteristics were not (Rickard and Vaughan, 1988). Soil quality (erosion and nutrient concentrations) was not assessed directly after plowing; however, litter mass (whose decomposition returns carbon, nitrogen, and other minerals to the soil) was measured and was found to be nine times less on the plowed fields than on the unplowed $B$. tectorum fields 2 years after plowing. This indicates that plowing degrades soil quality by reducing litter, and thus the return of organic matter and nutrients to the soil. The value of soil quality was reduced to 0 relative to the unplowed $B$. tectorum fields. Biotic quality was measured only by community shoot biomass and species composition of the flora on the site, not by animal and insect characteristics. Regardless, the studies provide a quantitative measure of the base of the shrub-steppe food chain, and thus a fair general indicator of biotic quality. Biotic quality was reduced to 0 immediately after plowing and into the following year. After 2 years, significant effects on shoot biomass, species composition, and vascular plant diversity persisted in both fields. Biomass was significantly higher in the plowed areas of the upper field, compared with unplowed areas $\left(302 \mathrm{~g} \mathrm{~m}^{-2} \mathrm{vs}\right.$. $\left.85 \mathrm{~g} \mathrm{~m}^{-2}\right)$, while it was significantly lower in plowed areas at the lower field $\left(160 \mathrm{~g} \mathrm{~m}^{-2} \mathrm{vs} .290 \mathrm{~g} \mathrm{~m}^{-2}\right.$ in unplowed areas). Plowing reduced the number of species from six to five in the upper field, while there was no effect on species number in the lower field. In both the upper and lower fields, two species appeared in the plowed ground of the upper field and two disappeared.

To determine what happens over the long term, detailed measurements of water, soil, and biotic characteristics were made in the Lower and Upper Snively old-fields and compared with similar measures taken in adjacent undisturbed shrub-steppe ecosystems by several investigators over the last 30 years (Rickard et al., 1988). Alien plant species have dominated the farmed area since 1943 with only minor indications of the reestablishment of native perennial species (Link et al., 1995).

In semi-arid regions, breaking soil by plowing greatly contributes to wind erosion of topsoil and reduction of air quality. However, air quality as indicated by particulates was not measured in these FEALE experiments because neither old-fields nor adjacent shrub-steppe habitat experience significant wind erosion. In old-field areas, dense cover of annual plants prevents wind erosion, while in shrub-steppe habitats, soil cryptogams provide this function. Fires also can remove plant material and damage cryptogams, leading to wind erosion. Wind erosion has been observed in low altitude $A$. tridentata $P$. sandbergii communities in sandy loam soils after fires have occurred (Hinds and Sauer, 1976).

In the shrub-steppe habitat, the severity of soil disturbance is high for plowed land but relatively low for moderate levels of livestock grazing (Beedlow, et al., 1988). Severe disturbance in arid ecosystems also reduces soil nutrients by mass loss due to wind erosion (Zonn et al., 1994). Wind erosion is high after severe disturbance of the ecosystem (Barrow, 1991). Wind erosion in old-fields and undisturbed areas is known to be very low, although rates of erosion have not been measured at FEALE. After 47 years without disturbance in the old fields, soil nitrogen was found to be the same at the ecosystem level in old fields and undisturbed areas (Bolton et al., 1990), although spacial patterns differed (West and Klemmedson, 1978). 
Plowing adversely affects the biological diversity of shrub-steppe systems, even when they are allowed to recover. The biotic quality of old-field sites was measured and compared to undisturbed areas. In the FEALE experiments, the native ecosystem exhibited higher biomass production $\left(1640 \mathrm{~g} \mathrm{~m}^{-2}\right)$ than the alien-dominated old-field area $\left(1205 \mathrm{~g} \mathrm{~m}^{-2}\right)$, so the old-field area received a relative biomassproduction score of 0.7 . (Refer to Table 4.) There appeared to be more vascular plant species in the native system (at least 20) than in the old-field area (at least 12) (Rickard and Vaughan, 1988), yielding a relative species-diversity score for the old-field area of 0.6. (Refer to Table 4.) The native habitat also had a higher population of small mammals (283/8000 trap nights vs. 88/8000 trap nights). Five insect species occurred in the shrub-steppe system and six occurred in the alien old-field system (Rogers et al., 1988). Finally, bird populations were higher in the native habitat $(41 / 500 \mathrm{~m}$ transect vs. $23 / 500 \mathrm{~m}$ transect) and were represented by more species (6 vs. 3) (Rogers et al., 1988). To summarize the effects of farming, bare plowed land rapidly loses both mass and soil nutrients and water quality declines. Recovery of ground cover stabilizes the soil in both the short and long run, but it appears that biotic quality does not recover, even after 50 years.

\section{Grazing}

Economically, cattle grazing is the most important use of the shrub-steppe habitat throughout the West. It is also the most widespread source of human-induced stress on the ecosystem (Rickard.and Vaughan, 1988). Grazing disturbance also has been studied at FEALE, which has been grazed by both cattle and sheep since the 19th century (Rickard and Vaughan, 1988; Hinds and Rogers, 1991). Even today, it is still possible to find sheep bedding areas because alien plant species continue to predominate in those areas. Light cattle grazing continued on FEALE until 1968, but none since. Rickard and Vaughan (1988) have described the effects of 3 years of light cattle grazing by measuring yearly shoot biomass. Although there have been no measurements at FEALE of the effects of grazing on air and water quality, adverse effects have been observed elsewhere.

Based on limited measurements, soil quality was degraded by grazing at FEALE (Wildung and Garland, 1988). Soil respiration decreased over a 2-year period on grazed land. The decrease was attributed to below-ground biological activity associated with above-ground photosynthetic activity. Other soil characteristics were not measured.

FEALE experiments showed that when cattle grazed on shrub-steppe habitat, short-term biotic quality was strongly affected. Herbaceous shoot biomass was reduced every year in grazed plots, compared with ungrazed plots. However, recovery was also rapid. A year after grazing ceased, no effect of cattle grazing was observed on either shoot biomass (Rickard and Vaughan, 1988) or small mammal populations (Rogers et al., 1988). Grazing did appear to reduce seed production, below-ground biomass, and standing dead biomass. At places where the animals congregated, the soil was broken, greatly disturbed, and invaded by alien plant species (Sisymbrium altissimum and B. tectorum) (Rickard and Vaughan, 1988). Population densities of insects and arthropods were similar in grazed and ungrazed habitats, with the exception of Pseudoregneria spicata clumps. In this microhabitat in the . 
month of April, mite density was found to be 3.3 times greater than in ungrazed plots (Rogers et al., 1988). In summary, the degree of degradation from grazing depends on the type and intensity of grazing. While some recovery from periodic and low-intensity grazing seems possible, intensive grazing degrades the biota, which contributes to increased wind and water erosion. Continuous grazing appears to lead to diminished shrub-steppe plant community, ecosystem, air, water, soil, and biotic quality.

\section{Valuation of Shrub-Steppe Ecosystem Functions}

As discussed above, the semi-arid, shrub-steppe habitat embodies ecological processes that benefit humans--maintenance of soil, water, and air quality; recreation opportunities; and biological diversity. Using the valuation framework proposed above, we consider how to measure these values. At the outset, we wish to emphasize the difficulty of estimating the value of environmental services provided by the shrub-steppe. Accordingly, the present study uses information from a variety of sources. We first examine the question of what the shrub steppe is worth if developed, or the opportunity cost of preservation.

\section{Opportunity Costs of Preservation}

Many different variables may explain the fair market value of land in its natural state, but location and prospects for its development appear to be among the most important. These depend on the physical, legal, and economic characteristics of the land. Importantly, different types of development have different effects on the ability of the land to perform some of its natural functions. For example, dryland farming reduces vegetative cover and the ability of the land to maintain clean air and water supplies. However, dryland farming may be compatible with some recreation uses; e.g., hunting.

Data used for estimating opportunity costs of shrub-steppe preservation were obtained from the Benton County Assessor's Office. They represent sales transactions in Benton County involving 7,700 acres during the year 1993-1994. During this period, 48 transactions were completed, ranging from 1.2 acres to 640 acres. The sample was screened to ensure that data represented land sales for all types of development. Consequently, the sample contains 17 property transactions for residential and/or commercial development, and 31 transactions involving property destined for agricultural development. Sales of predisposed agricultural land were further categorized based on whether the land was irrigated, or whether it would be used as dry pasture land or dry farmland. Summary statistics on the sample are shown in Table 5.

This classification scheme is specific to the study region during 1993-1994, and provides only a snapshot of the opportunity costs of preserving shrub-steppe. Our sampling of real estate transactions found that shrub-steppe for urban development had the highest average value, $\$ 9,208$ /acre. The average value of urban land is the most variable in terms of the coefficient of variation (CV), 0.64. Dry pasture land sold at an average value of $\$ 67 /$ acre, with roughly the same degree of variability. Irrigated farmland sold at an average value of $\$ 1484$, whereas dry agricultural land sold for $\$ 248$ /acre and had relatively less variability than either urban or pasture land. 
Table 5. Summary Statistics of Land Value Per Acre, 1993-1994, Benton County, Washington

\begin{tabular}{lcccc}
\hline \multicolumn{1}{c}{ Class } & Observations & Average & Variance & CV \\
\hline Urban & 17 & $\$ 9,208$ & $34,899,696$ & 0.64 \\
Irrigated Agriculture & 11 & $\$ 1,484$ & 255,255 & 0.34 \\
Dryland Agriculture & 9 & $\$ 248$ & 5,942 & 0.31 \\
Pasture & 11 & $\$ 67$ & 1,437 & 0.60 \\
\hline
\end{tabular}

Source: Benton County Assessor's Office

\section{Estimating Resource Values}

In this section, we attempt to quantify "resource values," or the social benefits from ecological functions and recreational uses of native shrub-steppe habitat. In some instances, these benefits are measured by the costs of replacing or maintaining these services using human analogs, such as various soil stabilization measures or the acquisition of hunting sites. In other instances, other valuation approaches are used to provide information on the willingness to pay for environmental amenities, such as the aesthetic value of cleaner air, or the recreational value of a hunting site. We begin with the valuation of soil stabilization, an ecological function performed by shrub-steppe habitat. This ecological value arises from mitigation of disutilites associated with wind erosion (blowing dust), principally from dryland farming.

\section{The Value of Soil Stabilization}

The argument that damages due to blowing dust can be reduced by preserving natural shrub-steppe ecosystems suggests an in-situ economic value associated with soil stabilization. To rationalize this argument we present two conventional willingness-to-pay measures for mitigating disutilites from blowing dust: hedonic damage values involving public health and safety and contingent-market values involving aesthetic quality. In contrast to these conventional willingness-to-pay estimates, we then consider the costs of using human analogs to replace or maintain the soil stabilization function inherent on natural shrub-steppe land. These values are presented below along with background information used in their estimation.

Pricing of Public Health and Safety. The possibility of estimating a damage value was explored for inconveniences due to road closures and maintenance following acute dust storms. Between July 1 , 1990 and June 30,1991 , various dust storms impaired driver visibility to the extent that 26 roads spanning 308 miles had to be closed for a period of 161 total hours in Benton-Franklin Counties. In 
addition, in the 11 episodes cited in Table 2, the excess traffic accidents cost an average of $\$ 2,413$ for property damage and $\$ 8,495$ per injury. The Washington State Department of Transportation estimated the administration of these road closures cost taxpayers $\$ 45,000$, and necessitated the clean-up of approximately 11,000 tons of wind-blown soil at about $\$ 200$ per ton from ditches and roads in 1990 . To complete the estimate, we assumed an instantaneous average vehicle loading on the rural highways involved in the closure of two vehicles per mile and an average delay cost of $\$ 25 /$ vehicle/hour during road closures. We also assumed that the primary acreage contributing dust were the dryland farms in Benton County, a total of about 91,000 acres (Washington State Department of Agriculture, 1993.

These facts and assumptions provide the basis for an estimate of the cost of wind-blown dust to the motoring public. On a per-acre basis, the cost is:

$$
\mathrm{C}=\frac{\left\{\sum \mathrm{P}_{\mathrm{PM}} \cdot[\text { Coll } \cdot \$ \operatorname{Cost} 1+\operatorname{Inj} \cdot \$ \operatorname{Cost} 2]\right\}+\operatorname{Cost} 3+\text { Miles } * \text { VEH } * \text { Hours } * \text { Cost } 4}{\text { Acres }}
$$

where $\mathrm{C}=$ cost of windblown dust to motoring public per acre of farm land

$$
\begin{aligned}
P_{\mathrm{PM}} & =\text { probability of an incident with } \mathrm{PM}_{10} \text { count exceeding } 150 \mu \mathrm{g} / \mathrm{m}^{3} \\
\text { Coll } & =\text { number of collisions per incident } \\
\text { Cost1 } & =\text { average property cost per collision } \\
\text { Inj } & =\text { number of injuries per incident } \\
\text { Cost2 } & =\text { average medical cost per injury } \\
\text { Cost3 } & =\text { average administrative costs per road closure } \\
\text { Hours } & =\text { average road closure hours per year } \\
\text { Miles } & =\text { average miles of road closed per closure } \\
\text { VEH } & =\text { average instantaneous traffic loading per mile of closed road } \\
\text { Cost4 } & =\text { average road closure cost per vehicle hour } \\
\text { Acres } & =\text { acres of land contributing to dust loading. }
\end{aligned}
$$

The probability of an incident where $\mathrm{PM}_{10}$ exceeds $150 \mu \mathrm{g} / \mathrm{m}^{3}$ was assumed to be the average incidence over the 3-year period reported in Table 2 for which we have records. Not all seasons are equally probable, since about 90 days in the summer are a low-wind period. The 11 incidents shown in 
Table 2 occurred over 3 years, with about 275 days/year as candidates. Based on this experience, the probability of $\mathrm{PM}_{10}$ exceeding $150 \mu \mathrm{g} / \mathrm{m}^{3}$ is about 0.0133 , for an expected number of 3.66 days/year. Using Equation (3), the average annual cost to traffic from occasional blowing dust incidents was about $\$ 52 /$ acre/year.

Acute Respiratory Effects. We also explored a hedonic damage value for acute respiratory effects associated with severe dust storms. An examination of these respiratory effects in Benton-Franklin Counties was undertaken by Hefflin et al., (1994). These authors considered the impacts of $\mathrm{PM}_{10}$ levels above $1000 \mu \mathrm{g} / \mathrm{m}^{3}$ on the number of emergency room (ER) visitations for respiratory disorders. Their study calculated the annual, monthly, and daily number of ER visits for respiratory disorders, and made correlations between ER visits, $\mathrm{PM}_{10}$ levels, and meteorological conditions (refer to Table 3). Based on Hefflin data, the number of emergency room visits during October 1991 increased above average by 112 cases. Given the average cost per visit to local emergency rooms was $\$ 200$ in November of 1991 , the estimated health care costs of $\mathrm{PM}_{10}$ levels above $1000 \mu \mathrm{g} / \mathrm{m}^{3}$ was $\$ 22,400$. We wish to emphasize that this hedonic damage value represents acute instances of fugitive dust emissions rather than chronic respiratory health effects from long-term exposures to high $\mathbf{P M}_{10}$ levels. The two high-dust days in October 1991 presumably contributed most of the 112 excess ER cases, an average of 56 per day, costing $\$ 11,200$. If we allow that the expected annual incidence of high-dust days is about 3.66 and that 91,000 acres contribute to the problem, the value per year of reducing ER visits by changing ground cover is only $\$ 0.45 /$ acre/year.

Household Cleaning Costs. In 1986, Huszar conducted a survey-based study to determine offsite annual household cleaning costs associated with wind erosion (Huszar 1989). From information gathered in the survey, the authors developed a damage function that links total annual household cleaning expenses to the wind-erosion rate (tons/acre), household income level, ownership of the property, and the number of years the family has lived at the present residence. Given this specification, Huszar estimated the following household cleaning cost function:

$$
\begin{array}{cccccc}
\ln \mathrm{TC}=2.98 & -0.14 \mathrm{X}^{-2} & -0.09 \mathrm{Y}^{2} & -0.01 \mathrm{Y}^{3} & -2.40 \mathrm{Z} & -0.02 \mathrm{~W} \\
(7.514) & (2.011) & (2.251) & (5.912) & (2.578)
\end{array}
$$

where $\mathrm{TC}=$ household costs from blowing dust

$$
\begin{aligned}
& X=\text { wind-erosion rate (tons/acre) } \\
& Y=\text { household income level }(1-8) \\
& Z=\text { own (2) or rent }(1), \text { and } \\
& W=\text { years at present residence. }
\end{aligned}
$$

Consistent with the original article, the wind-erosion rate, $\mathrm{X}$, is measured in tons of soil lost per acre of land in Benton-Franklin Counties. Household income level, $\mathrm{Y}$, was used as a proxy for property 
value using a integer index with 1 representing the lowest range (less than $\$ 5,000$ ) and 8 representing the highest (greater than $\$ 80,000$ ). Information on the number of households in Benton-Franklin Counties that lie within each income class was obtained from the 1990 U.S. Census. Length of residence and status of ownership in the two-county area were also factored into the valuation function. Ownership (2) showed greater costs for cleanliness relative to renting (1). In addition, Huszar's analysis found individuals' tolerance for dust increased with the length of residence, thereby having a negative impact on time and effort expended on household cleaning.

We conducted a sensitivity analysis of household cleaning costs to changes in the wind-erosion rate. Wind erosion is dependent on a variety of factors, most notably soil moisture, soil type, ground cover, and wind velocity. According to Holmes (1994), pristine shrub-steppe lands have an annual erosion rate between one-half and one ton per acre. Accordingly, this rate was used as a lower bound of household cleaning costs. Meanwhile, cropland in the two-county area experiences an annual winderosion rate of 10-15 tons/acre, or a soil depth approximately the width of a dime (Holmes, 1994). Therefore, 15 tons/acre was used as the upper bound estimate in our comparison of willingness to pay.

Fitting the local demographic and ecological information in the Huszar damage function yields annual household cleaning costs ranging from $\$ 375$ to $\$ 657$, or $\$ 137$ to $\$ 240$ per person. These estimates correspond to total household cleaning costs of $\$ 20.5$ million to $\$ 35.9$ million each year in BentonFranklin Counties. Figure 3 illustrates the cost per day for lower soil erosion in the two-county area, where the inverse of the soil-erosion rate represents the good being valued. At a soil-erosion rate of 15 tons/acre, the total cost in Benton-Franklin Counties is $\$ 98,315$ per day. Comparatively, the total cost is $\$ 56,193$ per day if the soil-erosion rate is .5 tons/acre, that which is found on natural shrubsteppe. The difference between the two, $\$ 42,122$, is an estimate of what the shrub-steppe's value is in reducing the daily household cleaning costs associated with offsite windblown dust. Multiplying by days of the year and dividing by 91,000 dryland farming acres, assumed to be the major source of soil erosion, yields $\$ 167 /$ acre/year.

A Point of Comparison: The Value of Visibility Associated with Windblown Dust. In the economists' lexicon the aesthetic quality of an environment is an example of a "public good:" its consumption or enjoyment by one individual does not infringe upon the consumption or enjoyment by other members of society. Thus, aesthetic qualities of an environment (e.g., clean air) must be valued as public goods. The empirical difficulties in doing so arise from the lack of market price information by which to directly measure individuals' willingness to pay for aesthetic quality. To overcome this problem, the environmental economics literature has developed various indirect methods for obtaining information on the values individuals place on aesthetic qualities; in particular, the method of contingent market valuation.

Contingent market valuation is a survey method in which individuals are asked what they would be willing to pay for increased aesthetic quality, or what they would be willing to accept as compensation for decreased aesthetic quality. This approach was used by Rowe et al. (1980) to estimate the value of visibility in the Four-Corners area. Using the contingent valuation estimates obtained by these authors, we developed a benefit-transfer model for the valuation of visibility in the Benton-Franklin study 


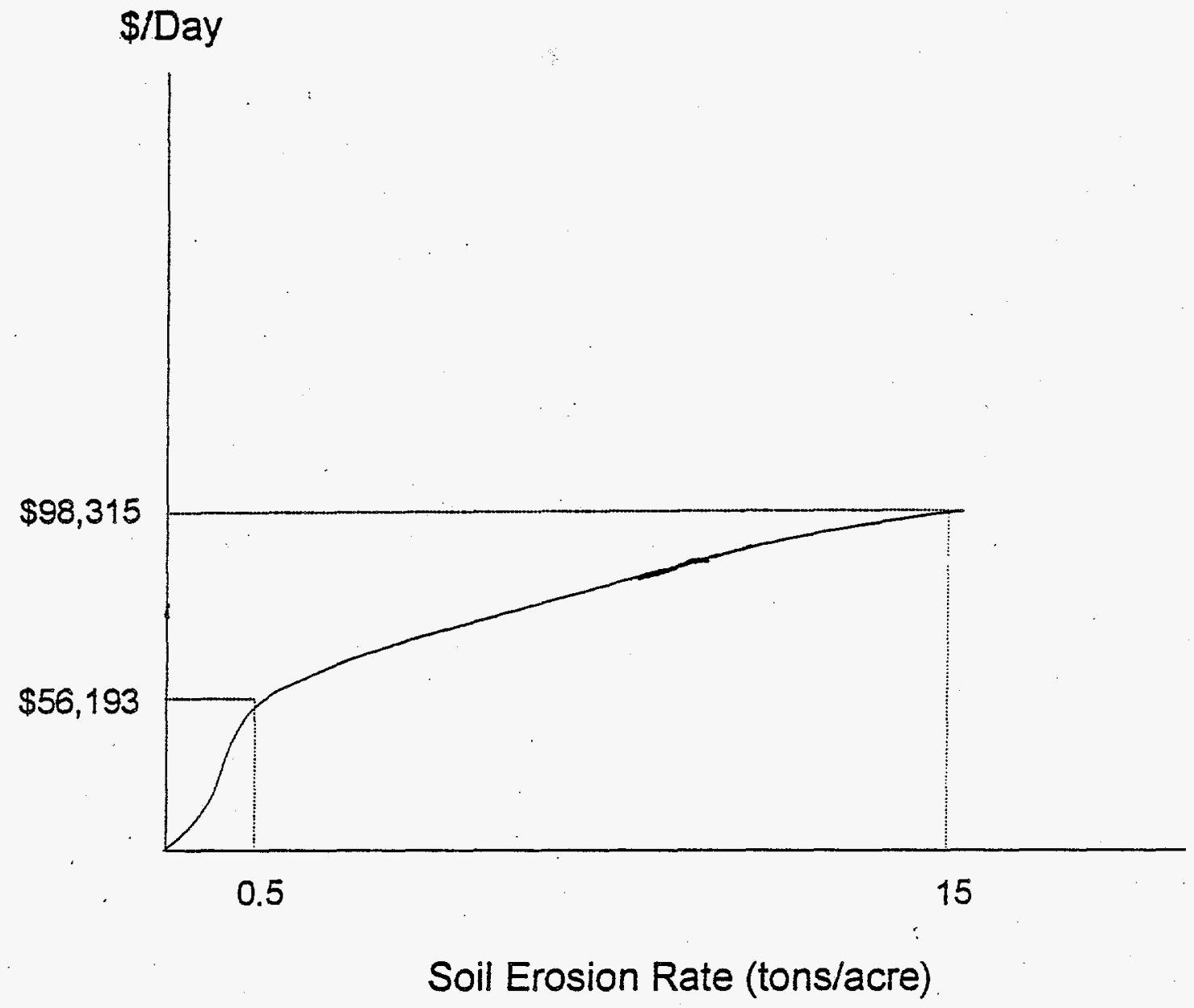

Figure 3. Estimated Household Cleaning Costs Associated with Soil Erosion in Benton and Franklin Counties, Washington

region to compare to the direct costs of wind erosion to traffic safety, public health, and household cleaning. In applying the contingent value-based parameter estimates to the Benton-Franklin study site, we accounted for a variety of socioeconomic and demographic site characteristics, and obtained "benefit-transfer" estimates of households' willingness to pay for improved visibility, i.e., reduction in airborne dust $\left(\mathrm{PM}_{10}\right.$ levels) and elimination of household cleaning expenditures.

The valuation of visibility in Benton-Franklin Counties falls in the realm of an aesthetic value in a local environment. The air quality problems in the region are reflected by the three highest $\mathrm{PM}_{10}$ values ever recorded in the U.S.: $1689 \mu \mathrm{g} / \mathrm{m}^{3}$ on October 16, 1991; 1166 on November 3, 1993; and 1035 on October 21, 1991. We provide a willingness-to-pay estimate to reduce these high $\mathbf{P M}_{10}$ levels using the method of "benefit-transfers." Our application of this method assigns willingness-to-pay estimates for improved visibility. 
Following Brookshire and Neil (1992), benefit transfers entail the transfer of existing environmental valuation estimates from one site to another. Therefore, benefit transfer studies involve reapplications of existing valuation data sets. In some instances, researchers use a direct application of previously estimated willingness to pay. In other situations, like ours, researchers take an indirect approach in the sense of utilizing critical parameter estimates from the initial study, and then adjusting these so as to reflect the socio-demographic characteristics of the "proposed application site." Since these indirect benefit transfers involve making adjustments for differences across sites, they are relatively less controversial than assuming that the initial estimates from one site apply directly to another site.

The practice of adopting information from a valuation study to transfer benefit values across sites requires that several empirical issues be considered. First, the "initial study site" and the proposed application site should be consistent in several ways: a) the commodity in question (visibility) should be identical across both sites; b) the populations affected by the quality of visibility should have similar demographic characteristics; and c) the assignment of property rights at both sites must lead to the same theoretically appropriate welfare measure, i.e., willingness to pay or willingness to accept.

Recognizing these issues, our willingness-to-pay estimates are based on parameter values derived by Rowe et al. (1980) using a contingent valuation survey instrument. In using these parameter estimates we note that our commodity specification (quality of visibility) is similar to the one evaluated by Rowe et al. (1980). However, to capture the aesthetic realities of our study site, air quality was measured using daily observations of $\mathrm{PM}_{10}$ over the period 1990-1994 provided by the Benton-Franklin County Clean Air Authority.

In addition, the site and sample characteristics of the population affected by lack of visibility were adjusted to reflect the Benton-Franklin County site. More precisely, we adjusted various independent variables using county-level census data on the urban/rural population, the age distribution, ethnicity and gender, and levels of household income. Upon making these adjustments, we found a measure of the collective willingness to pay across 54,000 households in the Benton-Franklin area of approximately $\$ 364,395$ per exceedence day; i.e., a day on which $\mathrm{PM}_{10}$ levels equal or exceed 150 micrograms per cubic meter, the safe minimum standards set by EPA under NAAQS (Figure 3). Again assuming that the probability of an exceedence day results in an expected 3.66 incidents per year and that 91,000 acres are responsible, the annual aggregate willingness to pay is $\$ 14: 66 /$ acre/year.

A Second Point of Comparison: The Cost of Restoring an Ecological Function. Although we used a conservative value of 15 tons/acre as a wind erosion rate for our calculations, wind erosion may be as high as 67 tons/acre/year on bare land in Benton-Franklin Counties (Holmes, 1994). In contrast, wind erosion loss on undisturbed shrub-steppe lands is estimated to be between one-half and one ton per acre per year (Holmes, 1994). The costs of reducing the differential between these soil-erosion levels suggests an alterative method of valuing soil stability. We consider two approaches presently used to control soil stabilization: the administration of the Conservation Reserve Program of the Soil Conservation Service of the U.S. Department of Agriculture, and the use of various human-engineered soil stabilization technologies. 
Under the Conservation Reserve Program, 123,720 acres of farmland were taken out of crop production in Benton and Franklin Counties in 1994. Once these lands are out of production, various engineering systems (human analogs) have been used to stabilize loose soils, including planting vegetative strips, or erecting windbreaks. Advocates of the Conservation Reserve Program suggest that the enrollment of lands predisposed to wind erosion, i.e., nominal farmlands, provide social value by reducing the severity of dust storms and $\mathrm{PM}_{10}$ levels. At the same time, Conservation Reserve Program proponents maintain nominal farmland is transformed into prime habitat for deer, pheasant, and other wildlife.

Initially (1986), Franklin County enrolled 1,700 acres in the Conservation Reserve Program, and Benton County enrolled 1,174. Currently, the Franklin County program occupies 84,000 acres costing $\$ 4$ million a year in annual payments to farmers, while the Benton County program presently enrolls 39,720 acres at a cost of $\$ 1.8$ mil/year. One estimate of the marginal value of soil stabilization is based on the returns to land enrolled in the Conservation Reserve Program.

The Conservation Reserve Program payment can be interpreted as the marginal value to farmers in forgoing the production of crops on the land. This amounts to an annual marginal value of approximately

$$
\frac{(\$ 1.8+\$ 4.0) \text { million per year }}{(84,000+39,720) \text { acres of land enrolled }}
$$

or $\$ 47 /$ acre/year. This is roughly halfway between the annualized value of dryland farms, $\$ 12 /$ acre/ year, and the annualized value of irrigated farmiand, \$74/acre/year. In perpetuity, the marginal value of an acre of Conservation Reserve Program land is $\$ 940$ using a discount rate of 5 percent. Economically, $\$ 47 /$ acre/year (or $\$ 940 /$ acre) represents the marginal value of land that is set aside in order to reduce soil-erosion losses (annually or in perpetuity). Table 6 illustrates the marginal value of land in the Conservation Reserve Program, along with the total amount of land enrolled in the two-county area. Increasing (decreasing) this payment above (below) $\$ 47 /$ acre/year would lead to more (less) enrollment of land in the Conservation Reserve Program.

A Third Point of Comparison: Costs of Soil Stabilization Techniques. Still another method of estimating the marginal value of soil stabilization is to consider the direct costs of employing soil stabilization technologies while maintaining the land in farming. We refer to these as human analogs in the sense that they provide soil stabilization through human-engineered systems that are designed to perform the ecological function of native shrub-steppe. These human analogs include windbreaks and vegetative strips on highly erodible soils used in dryland farming. The direct costs of employing these technologies are sensitive to both crop type and rotation cycle. For instance, in the case of continuous potato farming, vegetative strips cost $\$ 21.65 /$ acre/year/rotation and windbreaks cost $\$ 6.15$. In contrast, these same preventive measures cost less if winter wheat is planted following the potato harvest: $\$ 10.83$ for vegetative strips and $\$ 6.15$ for windbreaks. 
Table 6. Estimated Costs of Conservation Reserve Program Compared to Average Prices of Various Types of Land, in Benton and Franklin Counties, Washington (Dollars/Acre/Year)

\begin{tabular}{lc}
\hline \hline \multicolumn{1}{c}{ Land Type } & $\begin{array}{c}\text { Average Price/ } \\
\text { Acre/Year }\end{array}$ \\
\hline Urban & $\$ 460.40$ \\
Irrigated Farm & 74.20 \\
Conservation Reserve Program & 47 \\
Dryland Farm & 12.40 \\
Grazing & 3.35 \\
\hline \hline
\end{tabular}

The variation in the costs of soil stabilization technologies is due in large measure to the wide differences in wind erosion for the various crops types and rotation cycles; for example, under continuous potato farming, wind-erosion losses are estimated to be 37 tons/year, and 13 tons/year if the land is rotated between potato and winter wheat production. However, none of the systems reduces emissions to the 0.5 tons/acre characteristic of native shrub-steppe because all reported systems leave some bare soil.

To summarize the various values associated with stabilizing soil in Benton and Franklin Counties: we estimate that on an annual basis, the traffic costs, identifiable health costs, and extra cleaning costs associated with wind erosion of soil and exceedence of EPA's $\mathrm{PM}_{10}$ standards are $\$ 52 / \mathrm{acre}, \$ 0.45 /$ acre, and $\$ 168 /$ acre, respectively, which can be summed to yield $\$ 220 /$ acre/year. In comparison, based on benefit transfer studies, households in the area might be willing to pay up to $\$ 14$ /acre if visibility were improved so that the EPA standards were never violated. Because it is measured differently, it is not clear whether this contingent value for visibility actually represents an overlap with the costs outlined above or a separate component of value. Another point of comparison is the marginal cost of preventing wind erosion. Retiring bare land from production through the Conservation Reserve Program (and reducing erosion rates to those approaching native shrub-steppe) costs an average of \$47/acre/year, while keeping the land in farms and planting vegetative strips and windbreaks, although less effective, costs between $\$ 6 /$ acre/year and $\$ 22 /$ acre/year. The result appears to indicate that more land could be retired from farming and returned to continuous vegetation with a net economic benefit, even counting only off-farm soil erosion benefits. However, the benefit calculation is sensitive to what is assumed about the acreage responsible for wind-blown dust. If we had used the total acreage in both Benton and Franklin Counties planted in row crops $(318,000$ acres) as our denominator for the traffic, health, and cleaning costs, the value of these costs would have shrunk from $\$ 220 /$ acre/year to about $\$ 63 /$ acre/ year--still a "good deal," but a much closer call. 


\section{The Recreational Value of Hunting on Open Space}

Shrub-steppe land in the study region provides an open space for a variety of recreational uses, including upland game hunting. The recreational value of shrub-steppe land as hunting sites, depends on the environmental attributes of any given site. As before, our estimation of this preservation value involves the comparison between a willingness-to-pay estimate based on the application of travel cost methods to shrub-steppe sites, and the costs of replacing shrub-steppe hunting sites based on human analogs, e.g., game ranches. We first estimate the marginal replacement costs of the human analog, and then compare this estimate against the estimated willingness to pay for visits to shrub-steppe sites for purposes of upland bird hunting in Benton-Franklin Counties.

Set-Aside Hunting Sites. Several sources of information are used to estimate the willingness to pay for game hunting on shrub-steppe sites. First, replacement costs of shrub-steppe land for hunting are estimated from a recent (1994) sale of an undeveloped site in the Benton-Franklin County area. The site, known as the Barker Ranch, encompasses 2,000 acres in the Horn Rapids area along the Yakima River within the Benton County limits. According to the County Assessor's Office, the total amount of the sale was $\$ 3$ million. Private hunting clubs have used the property for years, and the new owners state that, "the property will remain in its current state for some time as a wildlife area for sportsmen." The property is populated with waterfowl, upland game birds, and small animals. Based on the sale value of the Barker Ranch, the replacement costs for shrub-steppe used in upland game hunting are approximately $\$ 1500$ /acre. Annualized at a discount rate of 5\% in perpetuity, this is approximately $\$ 75 /$ acre/year--about the price of irrigated land in the area.

Travel Cost-Based Estimate. We also derived a travel-cost-based estimate of willingness to pay for game hunting on shrub-steppe sites, based on information from the U.S. Department of Fish and Wildlife concerning the number of upland bird hunters using Benton-Franklin Counties, and information on the number of pheasant and quail harvested in the area (Department of Fish and Wildlife, State of Washington). Approximately 54 percent of the days spent hunting small game were used in the pursuit of pheasant and quail. Multiplying this ratio by the amount spent on food, lodging, transportation, and equipment when hunting small game yields an estimate of expenditures of over $\$ 11$ million for hunting the two upland game birds in Washington.

We prorated expenditures for Benton and Franklin Counties by adjusting this statewide estimate using a harvest ratio that compares the average annual pheasant and quail harvests in Benton and Franklin Counties relative to state averages. Thus we estimate that approximately $12 \%$ of the annual pheasant and quail harvests are taken in Benton and Franklin Counties (U.S. Fish and Wildlife Service and U.S. Bureau of the Census, 1993). It follows that over $\$ 1.3$ million is spent annually in the two-county region.

An alternative estimate of the value of shrub-steppe hunting sites is based on travel costs to these sites. This method was used to estimate willingness to pay for upland bird hunting in Benton-Franklin Counties. The logic behind the travel cost method is that willingness to pay for a recreational experience at a site can be inferred from the number of site visitations and travel costs to the site, 
where the number of visitations is inversely proportional to the travel cost (distance) (Clawson and Knetch, 1966). The required data were obtained from the Washington State Department of Fish and Wildlife (Upland Game Division) and the National 1991 Survey of Fishing, Hunting, and Wildlife Associated Recreation (U.S. Fish and Wildlife Service and U.S. Bureau of the Census, 1993). We apportioned travel by upland bird hunters to Benton-Franklin Counties into five zones based on state averages: those that travelled less than 25 miles to their hunting site; between 25 and 50 miles; between 50 and 100 miles; between 100 and 250 miles; and those that travelled over 250 miles to the site.

It is estimated that the average cost per small game hunter was $\$ 193$ in 1991 . We assumed this cost varies in proportion to distance travelled to Benton-Franklin counties. Based on this assumption, we estimated an average cost per zone by multiplying the average cost $(\mathrm{AC}=\$ 193)$ by the ratio of median distance in each zone $\left(d^{i}\right)$ to the average distance travelled (d), i.e.,

$$
A C_{i}=\left(\frac{d_{i}}{d}\right) \cdot \overline{A C}
$$

where $i=1-5$ represent zones.

Using this estimation of travel costs, willingness to pay for hunting shrub-steppe dependent game birds was calculated for each zone by multiplying the difference between the highest average cost (zone 5) and the average cost of the zone being considered by the number of hunters in that zone. Referring to Figure 4, willingness to pay was aggregated across zones, yielding $\$ 3.2$ million in annual recreational benefits. Assuming a $5 \%$ discount rate, the capitalized value is $\$ 64.2$ million.

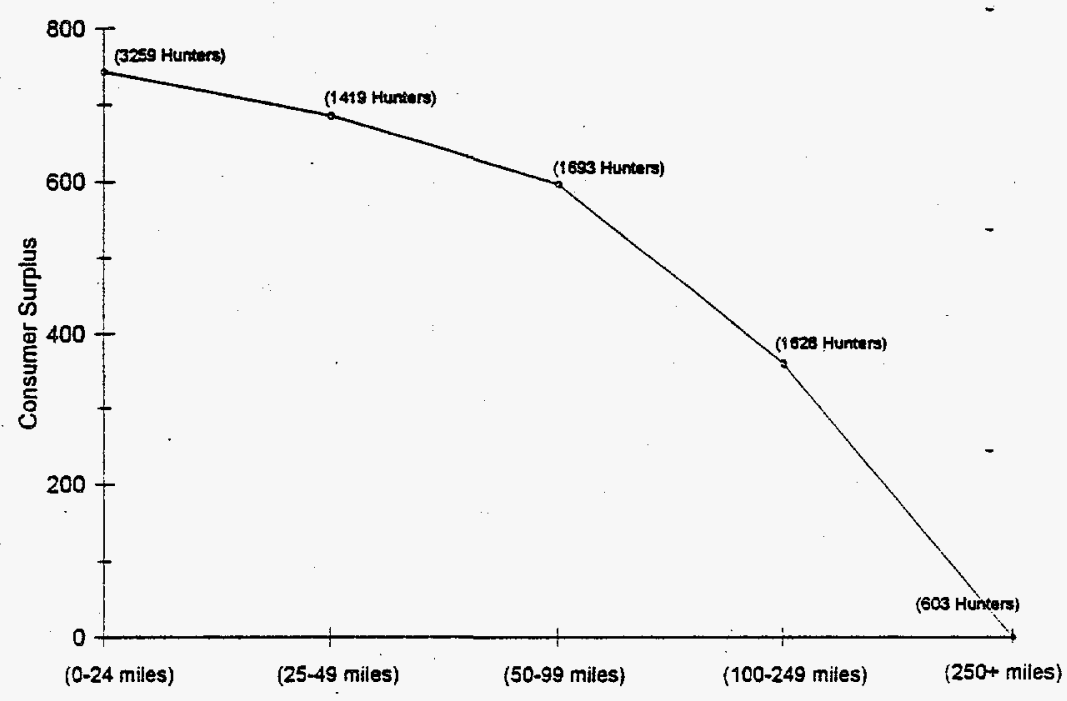

Figure 4. Aggregate Willingness-to-Pay for Hunting Upland Game Birds in Benton and Franklin Counties, Washington (Travel Cost Method) 
Officials of the Washington State Department of Fish and Wildlife estimate Benton-Franklin Counties contain 565,498 acres of land available for upland game bird hunting (Washington State Department of Fish and Wildlife, 1994). One could consider this acreage as an upper-bound estimate of the acres used by bird hunters in the two-county region. Dividing the capitalized value by the estimate of upland bird habitat acreage yields a value of $\$ 113.56 /$ acre or about $\$ 6 /$ acre/year on an annual basis. This value seems low in comparison with the \$75/acre/year paid for the Barker Ranch, until one realizes that 1) the Barker Ranch is probably better-than-average habitat and 2) the hunters involved in the purchase of the Barker Ranch have the option of restricting access, increasing the quality of the hunting experience.

\section{Biodiversity}

The function of maintaining shrub-steppe habitat for biodiversity is among the hardest to value of all the functions of this habitat. We base this value on a human analog--the costs of reestablishing ground cover with "natural" vegetation. General bid costs for revegetation of the shrub-steppe habitat in the Benton-Franklin County areas are about $\$ 1500$ /acre, for an annual value of about $\$ 75 /$ acre/year. However, it is not clear how effective revegetation would be if native grasses were used. Table 4 provides a lower-bound value for productivity of restored areas, since old-farm sites at the FEALE reserve that were allowed to naturally recover are dominated by alien species (weeds) and are only about 0.7 times as productive as native, undisturbed sites. Deliberate reseeding almost certainly would be more effective than this at reestablishing some native species, but even if ground cover is reestablished by reseeding with native grasses, it is not certain that the resulting "human analog" acres will be as efficient at providing the biodiversity function that humans value.

This disparity in productivity between disturbed and undisturbed shrub-steppe habitat has two possible interpretations for valuation of the undistrurbed habitat. First, one could assume that the value at the margin of an acre of undisturbed land must be greater than the cost of restoration since the undisturbed land is somehow more "valuable" in producing biodiversity. According to this view, the cost of restoring natural habitat would have to be adjusted upward to obtain the marginal value of undisturbed habitat. A simple linear adjustment based on the comparative old field results for shrub steppe at the FEALE Reserve would yield a relative marginal value of undisturbed land at $\$ 75 / 0.7$ (worst case) or $\$ 75 / 1.0$ (perfect restoration) yielding between $\$ 75$ and $\$ 107 /$ acre/year. $^{(a)}$

Another interpretation of human analog restoration costs is that the land management agency has a choice between preservation and restoration as competing methods to obtain biological diversity. It is not rational for a land management agency to restore biodiversity to farmlands (for example) at a biodiversity index of between 0.7 and 1.0 at $\$ 75 /$ acre/year if it can obtain a better quality habitat less expensively by simply preserving undisturbed habitat for "free"--that is, with no cost other than its

(a) The adjustment need not be linear. It may be that the value of the extra species or extra productivity of the undisturbed land is far greater than the physically-based $30 \%$ adjustment used here would suggest. It is also possible that the adjustment could be less than proportional. The same thing is true in the adjustment in the next paragraph. 
opportunity cost. (The acquisition cost is the same in both cases-with dryland farms, the agency pays the $\$ 12.40$ /acre/year; with preservation, it forgoes the $\$ 12.40$ /acre/year that it could earn by selling the land.) What is the value of this "free" service? Because of the undisturbed land's higher productivity, the marginal value of obtaining biodiversity by restoring disturbed lands with a biodiversity index of 0.7 to 1.0 is implicitly lower than if the agency could simply restore habitat to the value of 1.0 in the undisturbed habitat--in this case, with a linear adjustment, it is $(\$ 75 \times 0.7)$ to $(\$ 75 \times 1.0)=\$ 52$ to $\$ 75 /$ acre/year. Given a choice of methods, the land use agency should equate the marginal values of restored and undisturbed habitat, which should both be $\$ 52$ to $\$ 75 /$ acre/year.

Hence, the implicit threshold value for the biodiversity function alone is $\$ 52$ to $\$ 75 /$ acre/year at current habitat abundance, since restored land provides the other principal functions of the native habitat, soil stabilization and recreation, about as well as native habitat does. Thus, of all the functions discussed, only the value of biodiversity is involved in the choice between native habitat and exotic grasses.

\section{Summary}

In summary, shrub-steppe ecosystems can provide functions of considerable direct and indirect value to humans. Under current circumstances, the value of the soil stabilization function or biodiversity functions on their own could outweigh dryland farming at the margin, if land markets available expressed the preferences of people who bear the costs of traffic hazards and perform extra household cleaning as a result of blowing dust, or who value species diversity. The annualized per/acre values estimated in this paper are summarized in Table 7 (for both 91,000 acres and 318,000 acres of farmland in the case of wind erosion, since it is not clear how many acres contribute to the blowing dust problem).

We expect that many of these values would not show up in a conventional contingent valuation study because it would be extraordinarily difficult to provide respondents with enough background to appreciate the mechanisms underlying the functions discussed in this paper. Instead, we expect that a contingent valuation study would likely provide an estimate largely based on visibility, with only weak links to the underlying implications for land cover, and with no consideration at all of biodiversity issues.

The highest values shown in Table 7 appear to be based on soil stabilization, no matter how we measure the benefits of shrub-steppe. Because they leave erodible bare earth, farmed land, overgrazed land, and urban building sites (temporarily), appear to cause the offsite damage that accounts for the bulk of the shrub-steppe value. Attention to mitigation and maintaining ground cover to prevent blowing dust in inhabited regions could reduce that source of offsite damage. Similarly, grazed and farmed areas could be managed to maintain some important recreation values. However, that still leaves a value for biodiversity that might be as much as $\$ 52$ to $\$ 75 /$ year/acre under present circumstances. This value cannot be changed through mitigation. 
Table 7. Summary of Values Estimated for Shrub-Steppe Habitat (Dollars/Acre/Year)

\begin{tabular}{lll}
\hline \multicolumn{1}{c}{ Function } & \multicolumn{1}{c}{ Measurement Technique } & \multicolumn{1}{c}{$\begin{array}{c}\text { Annual Value } \\
\text { Per Acre (\$) }\end{array}$} \\
\hline Soil Stabilization & $\begin{array}{l}\text { Contingent valuation: benefits transfer to } \\
\text { reduce } \text { PM }_{10} \text { count } \\
\text { Cost of Conservation Reserve Program land } \\
\text { acquisition program } \\
\text { Cost of soil stabilization program with farming } \\
\text { (analog) }\end{array}$ & 4 to \\
& $\begin{array}{l}\text { Expected cost of traffic accidents and road } \\
\text { closures }\end{array}$ & 67 \\
& $\begin{array}{l}\text { Extra cleaning costs } \\
\text { Hunting club annualized rental value (analog) }\end{array}$ & 15 to 52 \\
Recreation & $\begin{array}{l}\text { Travel costs (WTP) } \\
\text { Annualized restoration costs, adjusted for } \\
\text { productivity }\end{array}$ & 48 to 169 \\
\hline \hline
\end{tabular}

\section{Conclusion}

This paper has demonstrated that with careful and imaginative use, environmental and economic data can be combined to obtain estimates of the value of environmental services of even the most ecological resources. Too much should not be made of the specific values in Table 7 , which derive from specific local circumstances in Benton and Franklin Counties in Washington State. However, they do suggest that undisturbed natural habitats have values worth preserving, whether or not conventional analysis can discover them. With respect to preservation, future work on valuation can be focused on those 
aspects of value that cannot be preserved when the land is converted to other uses. For land that is already converted, work can be focused on those aspects of value that can be mitigated through better management of vegetation and land cover.

In view of the values shown, has the right amount of land been converted to farming, ranching, and urban uses in the western United States? This paper offers no opinion on that matter. However, it does suggest that whenever such developments occur, the processes and functions of the natural habitat should be investigated, and attention should be given to low-cost ways to preserve these functions--even those functions that have no easily recognized market value. 


\section{References}

Adams, R. M., O. Bergland, W. N. Musser, S. L. Johnson, and L. M. Musser. 1989. "User Fees and Equity Issues in Public Hunting Expenditures: The Case of Ring-Necked Pheasant in Oregon." Land Economics 65(4): 376-393.

Barbier, E. B. 1994. "Valuing Environmental Functions: Tropical Wetlands," Land Economics. 70(2): 155-173.

Barrow, C. J. 1991. Land Degradation. Cambridge University Press, Cambridge, United Kingdom.

Batie, S. S., and C. C. Mabbs-Zeno. 1985. "Opportunity Costs of Preserving Coastal Wetlands: A Case Study of a Recreational Housing Development," Land Economics 60(1):1-9.

Beedlow, P. A., P. Van Voris, and L. E. Rogers. 1988. Theoretical Perspective on Ecosystem Disturbance and Recovery. In W. H. Rickard, L. E. Rogers, B. E. Vaughan, and S. F. Liebetrau (eds), Shrub Steppe Balance and Change in a Semi-Arid Terrestrial Ecosystem. Elsevier, Amsterdam, The Netherlands.

Bolton, Jr., H., J. L. Smith, and R. E. Wildung. 1990. "Nitrogen Mineralization Potentials of ShrubSteppe Soils with Different Disturbance Histories." Soil Science Society of America Journal 54:887-891.

Boyle, K. J. and J. C. Bergstrom. 1992. "Benefit Transfer Studies: Myths, Pragmatism, and Idealism." Water Resources Research 28(3):657-663.

Brookshire, D. S., and H. R. Neil. 1992. "Benefit Transfers: Conceptual and Empirical Issues." Water Resources Research 28(3):651-655.

Clawson, M., and J. L. Knetsch. 1966. Economics of Outdoor Recreation. Johns Hopkins University Press for Resources for the Future, Baltimore, Maryland.

Constanza, R., S. C. Farber, and J. Maxwell. 1989. "Valuation and Management of Wetland Ecosystems." Ecological Economics 1:335-361.

Gupta, T. R. and J. H. Foster. 1975. "Economic Criteria for Freshwater Wetland Policy in Massachusetts." American Journal of Agricultural Economics. February: 40-45.

Hefflin, B. J., et al. 1994. "Surveillance for Dust Storms and Respiratory Diseases in Washington State, 1991." Archives of Environmental Health 49(3):170-174.

Hinds, N. R., and L. E. Rogers. 1991. Ecological Perspectives of Land Use History: The Arid Lands Ecology (ALE) Reserve. PNL-7750, Pacific Northwest Laboratory, Richland, Washington. 
Hinds, N. R., and R. H. Sauer. 1976. Soil Erodibility, Soil Erosion, and Revegetation Following Wildfire in the Shrub-steppe Community. In Atmospheric-Surface Exchange of Particulate and Gaseous Pollutants. ERDA Symposium Series 38, CONF-740921.

Holmes, J. W. 1994. Wind Erosion and Dust Control in Irrigated Agriculture. Franklin Conservation District, Washington State Department of Ecology, January 1994.

Huszar, P. C. 1989. "Economics of Reducing Offsite Costs of Wind Erosion." Land Economics, 65(4):333-340.

Kneese, A. V. 1984. Measuring the Benefits of Clan Air and Water. Resources for the Future, Inc., Washington D.C.

King, A. W. 1993. Considerations of Scale and Hierarchy. In S. J. Woodley, J. Kay, and G. Francis (eds), Ecological Integrity and the Management of Ecosystems. St. Lucie Press.

Link, S. O., H. Bolton, Jr., M. E. Thiede, and W. H. Rickard. 1995. "Gas Exchange and Biomass of Downy Brome to Nitrogen and Water." Journal of Range Management 48 [In press].

Link, S. O., W. J. Waugh, and J. L. Downs. 1994. The Role of Plants in Isolation Barrier Systems. In G. W. Gee and N. R. Wing (eds.) In-Situ Remediation: Scientific Basis for Current and Future Technologies. Battelle Press, Columbus, Ohio.

Rickard, W. H., and B. E. Vaughan. 1988. Plant Community Characteristics and Responses. In W. H. Rickard, L. E. Rogers, B. E. Vaughan, and S. F. Liebetrau (eds), Shrub Steppe Balance and Change in a Semi-Arid Terrestrial Ecosystem. Elsevier, Amsterdam, The Netherlands.

Rickard, W. H., L. E. Rogers, B. E. Vaughan, and S. F. Liebetrau (eds). 1988. Shrub Steppe Balance and Change in a Semi-Arid Terrestrial Ecosystem. Elsevier, Amsterdam, The Netherlands.

Rogers, L. E., R. E. Fitzner, L. L. Cadwell, and B. E. Vaughan. 1988. Terrestrial Animal Habitats and Responses. In W. H. Rickard, L. E. Rogers, B. E. Vaughan, and S. F. Liebetrau (eds), Shrub Steppe Balance and Change in a Semi-Arid Terrestrial Ecosystem. Elsevier, Amsterdam, The Netherlands.

Rogers, L. E., and W. H. Rickard. 1988. Introduction: Shrub-steppe Lands. In W.H. Rickard, L. E. Rogers, B. E. Vaughan, and S. F. Liebetrau (eds), Shrub Steppe Balance and Change in a SemiArid Terrestrial Ecosystem. Elsevier, Amsterdam, The Netherlands.

Rowe, R. D., R. C. D'Arge, and D. S. Brookshire. 1980. "An Experiment on the Economic Value of Visibility". Journal of Environmental Economics and Management, 7(1):1-19.

Thorp, J. M., and W. T. Hinds. 1977. Microclimates of the Arid Lands Ecology Reserve 1968-1975. BNWL-SA-6231, Battelle Pacific Northwest Laboratories, Richland, Washington. 
U.S. Fish and Wildlife Service and U.S. Bureau of the Census. 1993. 1991 Survey of Fishing, Hunting, and Wildlife-Associated Recreation: Washington. U.S. Government Printing Office, Washington, D.C.

Washington State Department of Agriculture. 1993. Washington Agricultural County Data. Washington State Agricultural Statistics Service, Olympia, Washington.

Washington State Department of Fish and Wildlife. 1994. Upland Birds: Management Strategies. Washington State Department of Fish and Wildlife, Olympia, Washington.

West, N. E., and J. O. Klemmedson. 1978. Structural Distribution of Nitrogen in Desert Ecosystems. In N. E. West and J. Skujins (eds), Nitrogen in Desert Ecosystems. Dowden, Hutchinson, and Ross, Stroudsburg, Pennsylvania.

Wildlife Management Division. 1993. 1992-93 Game Harvest Report. Summer 1993. Washington State Department of Wildlife, Olympia, Washington.

Wildung, R. E., and T. R. Garland. 1988. Soils: Carbon and Mineral Cycling Processes. In W. H. Rickard, L. E. Rogers, B. E. Vaughan, and S. F. Liebetrau (eds), Shrub Steppe Balance and Change in a Semi-Arid Terrestrial Ecosystem. Elsevier, Amsterdam, The Netherlands.

Wohld, M. 1991. Horse Heaven Farmers Battling Wind Erosion. Washington Farmer-Stockman. April 1991:10-A.

Zonn, I., M. H. Glantz, A. Rubenstein. 1994. The Virgin Lands Scheme in the Former Soviet Union. In M. H. Glantz (ed), Drought Follows the Plow. Cambridge University Press, Cambridge, United Kingdom. 


\section{Distribution}

No. of

Copies

\section{OFFSITE}

12 DOE/Office of Scientific and Technical Information

\section{ONSITE}

48 Pacific Northwest Laboratory
C. W. Abrams
G. B. Bilyard (23)
C. A. Brandt
S. L. Friant
E. A. Flores
B. A. Garrett
S. W. Gajewski
K8-03
K8-03
K6-84
K6-77
K8-12
K8-09
K8-03

No. of

Copies
M. J. Graham K9-38
V. J. Hamilton K8-09
R. N. Kickert K6-84
S. O. Link K6-84
C. A. McAllister K8-03
D. A. Neitzel K6-54
K. M. Probasco K6-77
L. E. Rogers K6-84
M. J. Scott K8-03
H. E. Seely K8-17
C. A. Ulibarri K8-03
H. E. Westerdahl K6-75
J. A. Wise K7-28
Publishing Coordination
Technical Report Files (5) 